Збірник наукових праць Української державної академії залізничного транспорту

УДК 656.212.7

Канд. техн. наук О.М. Костєнніков

Cand. of techn. sciences O.M. Kostennikov

\title{
ФОРМУВАННЯ СИСТЕМИ ПІДТРИМКИ ПРИЙНЯТТЯ РІШЕНЬ ОПЕРАТИВНИХ ПРАЦІВНИКІВ ПРИ ВИКОНАННІ МІСЦЕВОЇ РОБОТИ НА ЗАЛІЗНИЧНИХ ПОЛІГОНАХ
}

\section{FORMING A SYSTEM OF DECISIONMAKING OF OPERATIONAL STAFF DURING LOCAL WORK USAGE ON RAILWAY POLIGONS}

Представив д-р техн. наук, професор А.М. Котенко

Постановка проблеми у загальному вигляді, іiї зв'язок із важливими науковими та практичними завданнями. На сьогодні організація місцевої роботи провадиться диспетчером відповідно до ситуації, що є на дільниці, не враховуючи техніко-економічні показники ефективності по призначенню вивізного поїзда, диспетчерського локомотива, збірного поїзда і ін., що $є$ суттєвим недоліком в 
оперативному управлінні місцевою роботою. Отже, виникає необхідність створення системи, що в автоматичному режимі визначатиме оптимальні регулювальні заходи щодо раціональної підв'язки локомотивів під місцеві состави для формування збірних та вивізних поїздів, ступінчатих маршрутів, призначення диспетчерських локомотивів.

Мета дослідження. Розробити пропозиції щодо формування системи підтримки прийняття рішень оперативних працівників при виконанні місцевої роботи на залізничних полігонах.

Виклад основного матеріалу. При побудові системи підтримки прийняття рішень (СППР) необхідно дотримуватися таких основних принципів: дружність по відношенню до користувача, відкритість, модульність і можливість реконфігурації системи, можливість вибору алгоритму вирішення поставленої задачі, здатність аналізу своїх дій, можливість придбання і формалізації нових знань [1,2].

Дружність системи по відношенню до користувача передбачає високий рівень адаптації системи до його вимог. Реалізація даного принципу дозволяє використовувати розроблену СППР спеціалістами, які не мають поглиблених знань у сфері комп'ютерних технологій. Адаптація досягається шляхом використання в системі діалогового режиму i зручного інтерфейсу для людини, яка приймає рішення (ЛПР).

Відкритість системи досягається можливістю розширення кола задач, які вирішує СППР шляхом використання для різних задач загального математичного апарату, програмного забезпечення конфігурації системи. Реалізація даного принципу також дозволяє легко адаптуватися СППР до нових задач, що досягається за допомогою доповнення системи новими даними, знаннями, моделями, а також математичними методами, які використовуються при формалізації знань та прийнятті рішень.
Модульність

забезпечує декомпозицію задач, що вирішуються при проектуванні і розширенні функціональних можливостей системи. Даний принцип передбачає побудову СППР із окремих функціональних модулів, що взаємодіють між собою. Це дає можливість легко вносити зміни в склад кожного модуля, зберігаючи структуру системи i існуючі між модулями взаємозв'язки.

Реконфігурація надає можливість зміни конфігурації системи 3 метою адаптації до нових умов або типу завдання, що вирішується. Можливість вибору алгоритму вирішення задачі забезпечує визначення системою за участю ЛПР методології вирішення поставленого завдання. Можливість аналізу своїх дій надає ЛПР можливість отримати в зручній для розуміння формі $\mathrm{i}$ термінології пояснення знань СППР i рішення, яке приймається системою. Можливість надбання формалізації нових знань забезпечує поповнення бази знань не тільки працівниками СППР, але і самою системою в процесі функціонування.

Система управління базою даних (СУБД) забезпечує задоволення інформаційних потреб СППР шляхом надання ЛПР та іншим функціональним модулям системи можливостей швидкого доступу до даних для отримання інформації, що використовується при прийнятті рішень [3]. Тому СУБД відповідає не тільки за зберігання відповідної моделі подання даних, але й за роботу даних різних програм та користувачів.

Отже, на основі вищезазначеного можна зробити висновок про необхідність побудови СППР модульного типу, де кожен окремий модуль буде вирішувати поставлені задачі.

У завдання системи входить реалізація апарату підтримки оперативних рішень поїзного диспетчера, що керує місцевою роботою дільниці. Це втілюється у вигляді оцінки ситуації, яка виникає в 
процесі роботи, та використовуючи минулий досвід запропонувати найбільш раціональний варіант організації місцевої роботи.
Критерій оптимальності рішення, що приймається, 3 ефективного управління системою на деякому часовому інтервалі можна записати в такому вигляді:

$$
\begin{gathered}
J=\operatorname{extr}[F(x, y, z, t)] \\
x \in R[x], y \in R[y], z \in R[z], t \in \Delta T,
\end{gathered}
$$

де $x, y, z$ - функції, які характеризують входи, виходи та внутрішній стан системи на розглядуваному інтервалі часу $\Delta T$;

$$
R[x], \quad R[y] R[z] \text { - обмеження, що }
$$
накладаються на дані функції.

Ефективність заходів щодо ефективного управління місцевою роботою в значній мірі пов'язана 3 обгрунтованістю прийнятих рішень щодо вибору типу поїзда для обслуговування станцій дільниці, виду локомотивів, що працюють на дільниці. Накопичений досвід моделювання великих систем та складних технологічних процесів дозволяє створювати СППР, що не тільки надають користувачу всю необхідну для прийняття рішень інформацію, але і забезпечують самостійне формування обгрунтованого рішення 3 кількісною оцінкою критерію, що характеризує його оптимальність [4].

Основу архітектури СППР старшого поїзного диспетчера (рис. 1) складають моделюючий, вирішальний, інформаційний та керуючий модулі, a також модуль організації діалогу та введення в систему інформації про розміщені в межах дільниці станції. Для зв'язку між модулями використовується інформаційно-керуюча системна шина, яка забезпечує передачу керуючих сигналів та інформації, що необхідна для вирішення поставлених перед системою задач [5].

Під оптимізаційними задачами в СППР маються на увазі мінімальний за витратами вибір станцій, які обслуговуються ступінчатими маршрутами, збірними поїздами, вивізними та диспетчерськими локомотивами. Метою раціоналізації $є$ пошук одного 3 множини варіантів обслуговування станцій дільниці. Залежно від задачі, яка вирішується, запропонований користувачу варіант має забезпечувати мінімально можливий, при заданих обсягах, простій вагонів при мінімальних витратах.

Ще однією функцією вирішального модуля $є$ аналіз запропонованих системою та людиною варіантів вирішення кожної із задач, що розглядаються. Після отримання від системи рекомендованого варіанта, людині, яка приймає рішення (ЛПР), надається можливість або погодитися с запропонованим СППР варіантом, або змінити його на свій розсуд, попередньо оцінивши за допомогою системи обгрунтованість прийнятого рішення.

Інформаційно-інтелектуальний

модуль СППР зберігає необхідні для функціонування системи бази даних, a також базу знань, яка призначена для зберігання основаних на досвіді спеціалістів алгоритмів, які використовуються в процесі прийняття рішень. Для зберігання даних у системі створено декілька баз, сформованих 3 урахуванням виду інформації, що надається користувачу.

Нові інформаційні технології автоматизованої системи керування вантажними перевезеннями Укрзалізниці (АСК ВП УЗ) забезпечують ведення вищезазначених баз даних та містять повну інформацію про поїзди, вагони, станції і ін. Інформація в БД АСК ВП УЗ постійно оновлюється та підтримується в актуальному стані [6]. 


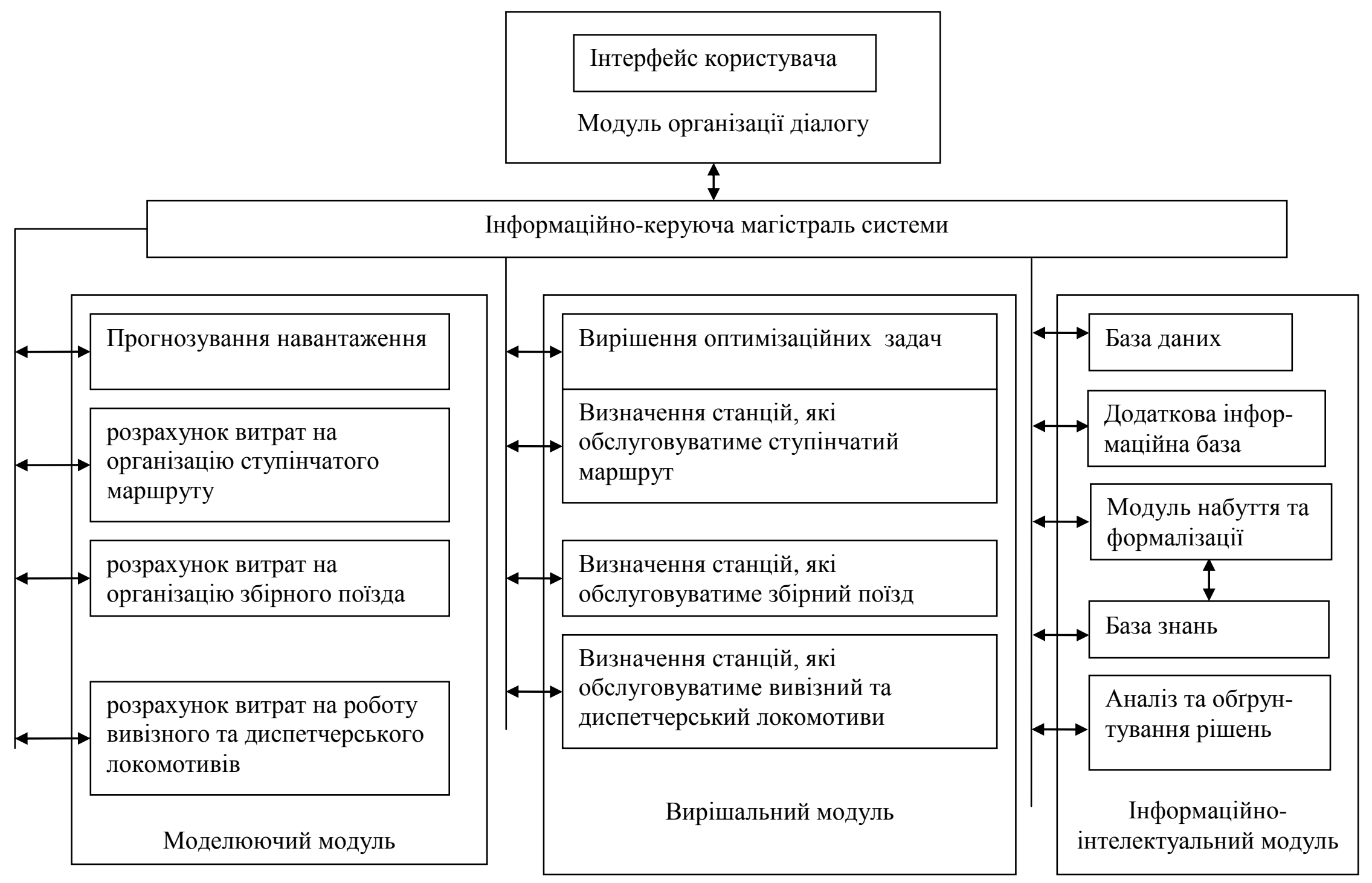

Рис. 1. Функціональна схема системи підтримки прийняття рішень у задачах управління місцевою роботою на залізничних полігонах 
Розгалуженість інформаційної бази АСК ВП УЗ дозволяє побудувати схему передачі інформації та організації БД у розробленій СППР (рис. 2).

За допомогою вищенаведеної схеми будь-який працівник може отримати потрібну інформацію відповідно до прав доступу до бази даних системи. Це дозволить вирішити проблему оперативної перевірки з боку керівництва, оскільки дає можливість у будь-який зручний момент часу отримати доступ до даних будь-якої станції або лінійного об'єкта.

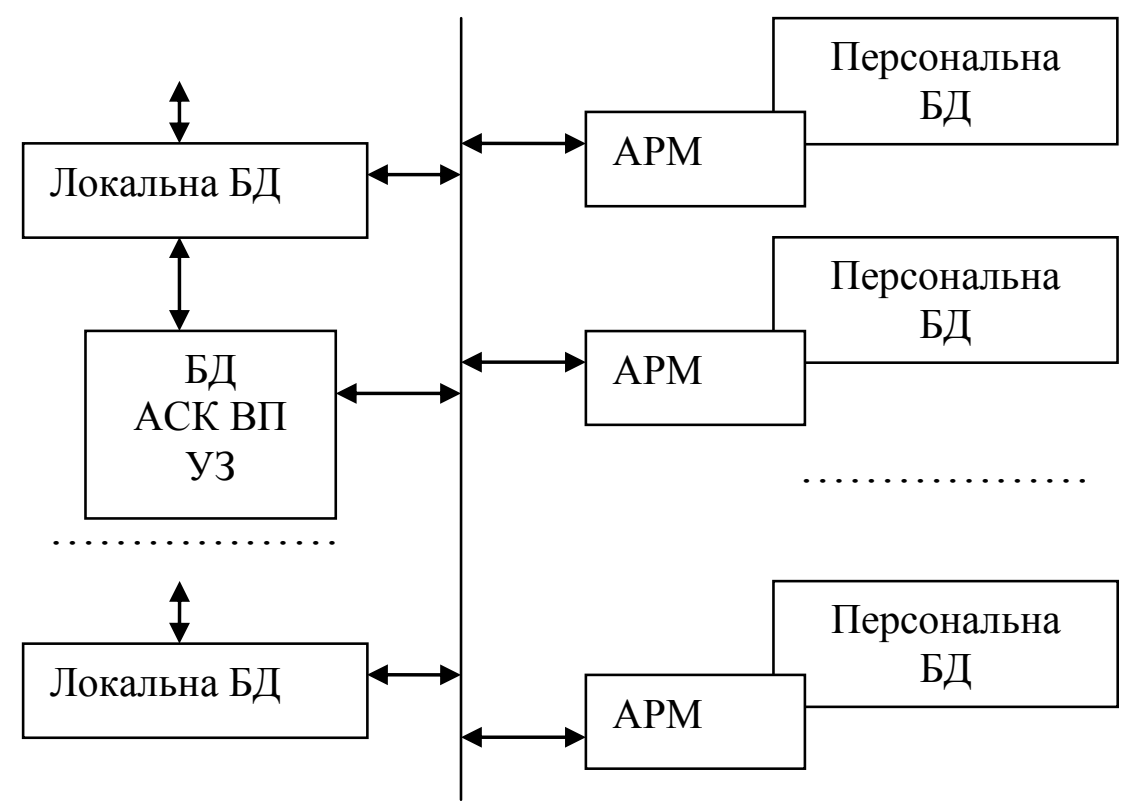

Рис. 2. Схема передачі інформації при функціонуванні СППР

Для перетворення повідомлень системи АСК ВП УЗ у запит бази даних для здійснення вибірки необхідних даних до розробленої СППР існує розроблений пристрій узгодження. Основна функція такого пристрою - перетворення даних системи АСК ВП УЗ у запит бази даних.

Додаткова інформаційна база використовується для зберігання інформації, що безпосередньо не бере участі при вирішенні поставлених СППР задач, але є необхідною для користувача. Наприклад, такою інформацією можуть бути: відомості різних нормативних актів, вказівок, інструкцій, даних про проведення організаційно-профілактичних заходів і т.д., що використовуються як нагадування для користувача СППР.
Всі програми, які входять у СППР, виконані 3 використанням методу структурованого програмування у вигляді окремих, призначених для вирішення конкретної задачі, функціонально орієнтованих модулів. Об'єднання програмних компонент виконується шляхом спеціальної конфігураційної програми, яка забезпечує побудову та функціонування СППР відповідно до архітектури, яка запропонована на рис. 1. Розроблена СППР реалізована в середовищі пакета прикладних програм Mathlab та оптимізована для роботи в операційному середовищі Microsoft Windows.

Отже, СППР спочатку визначає кількість вагонів під навантаження для кожного клієнта всіх станцій полігону 
дирекції залізничних перевезень (ДН) [9]. На наступному етапі автоматизована система визначає бальні характеристики лінійних об'єктів, з яких буде вивозитися місцевий вантаж [7].

Встановлення розробленої автоматизованої системи підтримки прийняття рішень передбачається на автоматизованому робочому місці старшого поїзного диспетчера, оскільки, як зазначалося раніше, саме він повинен забезпечити узгоджену роботу усього полігону ПД при виконанні експлуатаційного процесу, в тому числі й місцевої роботи.

Робота 3 СППР виконується за допомогою спеціального інтерфейсу (рис. 3). Відповідно до розробленої моделі управління місцевою роботою на диспетчерській дільниці [7] та методики техніко-економічної оцінки доцільності призначення певних категорій поїздів [8] виконано моделювання на досліджуваному полігоні. Таким полігоном стала Полтавська дирекція залізничних перевезень Південної залізниці (рис. 3).

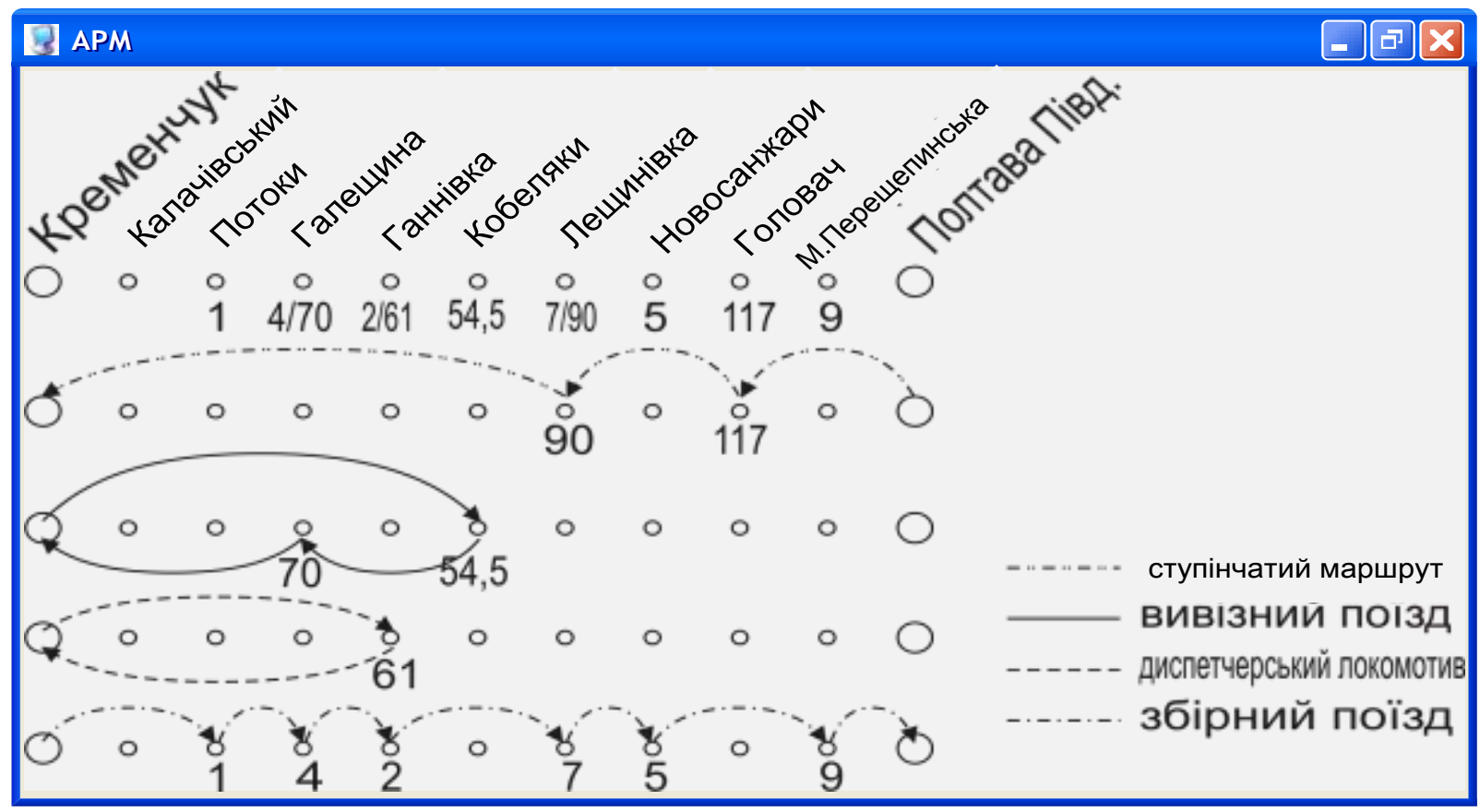

Рис. 3. Фрагмент інтерфейсу робочого місця старшого поїзного диспетчера з результатами моделювання управління місцевою роботою на дільниці Кременчук - Полтава-Південна

\section{Висновки та перспективи} подальших досліджень. На основі аналізу існуючих технологій формування системи підтримки прийняття рішень для зменшення впливу «людського фактора» при управлінні місцевою роботою у складній підсистемі, до якої доцільно віднести полігон дирекції залізничних перевезень, запропоновано удосконалену структуру інформаційно-керуючої системи полігону дирекції залізничних перевезень та додатковий комплекс задач. Запропонована автоматизована технологія управління місцевою роботою дозволяє раціонально 3 мінімальними експлуатаційними витратами використовувати рухомий склад, зокрема мінімізувати непродуктивні простої вагонів на станціях навантаження та пробіги локомотивів.

Сформований графічний інтерфейс для автоматизованого робочого місця старшого поїзного диспетчера та поїзного 
диспетчера являє собою добовий план місцевої роботи полігону дирекції залізничних перевезень з поїздами різних категорій. Для більш ефективної роботи доцільно передбачити безпосереднє дублювання вхідної інформації 3 АРМ старшого поїзного диспетчера (ДНЦС) до АРМ поїзного диспетчера (ДНЦ).

\section{Список літератури}

1. Змитрович, А.И. Интеллектуальные информационные системы [Текст] / А.И. Змитрович. - Минск: ТетраСистемс, 1997. - 367 с.

2. Синюк, В.Г. СППР: основные понятия и вопросы применения [Текст] / В.Г. Синюк, А.П. Котельников. - Белгород, 1998. - 79 с.

3. Parsaye, K.A. Characterization of Data Mining Technologies and Processes/ K.A. Parsaye // The Journal of Data Warehousing. - 1998. - № 1. - P. 12-24.

4. Матвеев, Л.А. Информационные системы: Поддержка принятия решений [Текст] / Л.А. Матвеев. - С.Пб., 1996. - 242 с.

5. Меркулов, А.В. Применение компьютерных технологий при создании сложных информационно-управляющих систем на железнодорожном транспорте [Текст] / А.В. Меркулов. - Ч. 1,2. - Хабаровск: ДВГУПС, 2003. - 382 с.

6. Атре, Ш. Структурный подход к организации баз данных [Текст] / Ш. Атре. - М.: Финансы и статистика, 1983. - 320 с.

7. Костєнніков, О.М. Формалізація технології організації місцевої роботи на полігоні дирекції залізничних перевезень [Текст] / О.М. Костєнніков // Зб. наук. праць. - Харків: УкрДАЗТ, 2012. - Вип. 134. - С. 27-34

8. Запара, В.М. Регулювальні заходи для оперативного управління місцевою роботою при збільшенні обсягів перевезень сезонних вантажів [Текст] / В.М. Запара, Д.І. Мкртичьян, О.М. Костєнніков, О.В. Ковальова // Зб. наук. праць. - Харків: УкрДАЗТ, 2009. - Вип. 111. C. $48-57$.

9. Мкртичьян, Д.І. Розроблення математичної моделі прогнозування обсягів навантаження 3 використанням нейро-нечіткого моделювання [Текст] / Д.І. Мкртичьян, О.В. Розсоха, О.М. Костєнніков, С.А. Ільченко // Зб. наук. праць. - Харків: УкрДАЗТ, 2012. Вип. 133. - С. 45-51.

Ключові слова: система підтримки прийняття рішень, місцева робота, оптимальний план роботи, старший поїзний диспетчер, автоматизоване робоче місце.

\section{Анотації}

Запропоновано удосконалену структуру інформаційно-керуючої системи полігону дирекції залізничних перевезень та автоматизовану технологію управління місцевою роботою, що дозволяє раціонально 3 мінімальними експлуатаційними витратами використовувати рухомий склад, зокрема мінімізувати непродуктивні простої вагонів на станціях навантаження та пробіги локомотивів. Сформований графічний інтерфейс на автоматизоване робоче місце старшого поїзного диспетчера та поїзного диспетчера являє собою добовий план місцевої роботи полігону дирекції залізничних перевезень 3 поїздами різних категорій.

Предложена усовершенствованная структура информационно-управляющей системы полигона дирекции железнодорожных перевозок и автоматизированная технология 
управления местной работой, что позволяет рационально с минимальными эксплуатационными затратами использовать подвижной состав, в частности минимизировать непроизводительные простои вагонов на станциях погрузки и пробеги локомотивов. Сформированный графический интерфейс на автоматизированное рабочее место старшего поездного диспетчера и поездного диспетчера представляет собой суточный план местной работы полигона дирекции железнодорожных перевозок с поездами различных категорий.

Offered to improve the structure of management information system landfill management of rail transportation and automated technology management in local work, which allows efficiently with minimal operating costs to use the particular stock to minimize unproductive downtime at the station for loading and runs locomotives. Formed workstation senior train dispatcher and train dispatcher is a daily local work plan landfill management of rail transportation with trains of different categories. 